\title{
Strategi pengembangan pariwisata daerah dan pemberdayaan masyarakat di Parigi Moutong
}

\section{Development strategy of regional tourism and community empowerment in Parigi Moutong}

\author{
$\underline{\text { Soedarso }}^{1}$, Sutikno $^{2}$ dan Sukardi $^{3}$
}

1) Pusat Studi Potensi Daerah dan Pemberdayaan Masyarakat, LPPM ITS Surabaya

2) Jurusan Statistika, FMIPA ITS, Pusat Studi Potensi Daerah dan Pemberdayaan

Masyarakat, LPPM ITS, Surabaya

3) STMIK Adhi Guna, Palu

E-mail: soedarsoits@gmail.com

\begin{abstract}
Community empowerment program in Parigi Moutong district has not been effectively operated, that greater effort to evaluate and develop the previously implemented program is needed. This research uses purposive sampling method, i.e. the chosen sample method. The study result finds that the cause of the community empowerment program that has been done is still not effective because the process of the determining program is lacking of public participation. As a result, it creates a new helplessness, i.e. the dependence of communities on the program with direct assistance. On the other hand, the regional tourism development program has a good prospect and able to synergized with a more participative community empowerment program that. The beauty of Parigi Moutong natural landscape and its possesion of various natural resources is a great potential to create a tourism destination, and enhancing society's welfare around the area.
\end{abstract}

Keywords: Parigi Moutong, community empowerment, tourism development, synergy, social welfare

\begin{abstract}
Abstrak
Program pemberdayaan masyarakat di Kabupaten Parigi Moutong belum sepenuhnya berjalan efektif, oleh karena itu diperlukan upaya untuk lebih memahami, mengevaluasi dan mengembangkan program-program yang telah dilakukan. Penelitian ini menggunakan metode survei dengan purposive sampling, yakni metode sampel secara terpilih. Hasil penelitian menemukan bahwa penyebab program pemberdayaan masyarakat yang sudah dilakukan masih belum efektif, karena proses penentuan program kurang melibatkan partisipasi masyarakat. Akibatnya, justru menciptakan ketakberdayaan baru, yaitu kebergantungan masyarakat terhadap program bantuan-bantuan langsung tersebut. Di sisi lain, program pengembangan pariwisata daerah memiliki prospek yang baik dan mampu bersinergi dengan program pemberdayaan masyarakat yang lebih partisipatif. Kondisi keindahan dan kekayaan alam Parigi Moutong potensial dikembangkan sebagai destinasi pariwisata sebagai upaya pemberdayaan masyarakat untuk meningkatkan kesejahteraan sosial masyarakat.
\end{abstract}

Kata kunci: Parigi Moutong, pemberdayaan masyarakat, pengembangan pariwisata, bersinergi, kesejahteraan sosial masyarakat

\section{Pendahuluan}

Parigi Moutong merupakan wilayah kaya dan luas mencapai 6.231,85 Ha, dengan garis pantai yang membentang sangat panjang sejauh $427 \mathrm{Km}$. Parigi Moutong sebelumnya merupakan bagian dari Kabupaten Donggala, namun kemudian pada tanggal 10 April 2002 dengan ketetapan UndangUndang RI Nomor 10 Tahun 2002, Parigi Moutong merupakan sebuah kabupaten tersendiri. Parigi Moutong sebagai sebuah kabupaten yang relatif baru di Provinsi Sulawesi Tengah, meskipun didukung dengan kekayaan alam yang melimpah, akan tetapi Indeks Pembangunan Manusia (IPM) masih lebih rendah daripada rata-rata IPM Propinsi Sulawesi Tengah. Tercatat IPM Kabupaten Parigi 
Moutong tahun 2012 sebesar 69,75, sedangkan IPM Propinsi Sulawesi Tengah tahun 2012 sebesar 72,14 (Pemerintah Kabupaten Parigi Moutong).

Keindahan akan alam Parigi Moutong sudah mendapat banyak pengakuan, bentangan pantainya yang memanjang mengelilingi Teluk Tomini, dan juga kontur geografis perbukitan yang subur membentang sepanjang wilayah Parigi Moutong. Kekayaan dan keindahan bawah lautnya juga sangat menarik dimiliki wilayah ini. Pengakuan terhadap kuatnya daya tarik akan keindahan alam Parigi Moutong diwujudkan dengan diadakannya acara yang bertaraf internasional "Sail Tomini" pada bulan September 2015, di samping juga terdapat acara rutin diadakan festival Teluk Tomini setiap tahun.

Di sisi lain, sebagai sebuah kabupaten baru, Parigi Moutong berada di bawah kemajuan wilayahwilayah lain di Provinsi Sulawesi Tengah. Kekayaan potensi alam yang berbanding terbalik dengan tingginya tingkat kemiskinan sebagian besar masyarakat menjadi problematika menarik untuk menemukan akar persoalan dan pemecahannya. Hal ini yang antara lain melatarbelakangi diadakan penelitian ini. Penelitian ini bersumber dari dana Hibah Penelitian Skema Eastern Part of Indonesia University Network (EPI-Unet) ITS tahun 2015-2016 yang dilaksanakan melalui kerjasama antara Pusat Studi Potensi Daerah dan Pemberdayaan Masyarakat LPPM ITS dengan STMIK Adhi Guna Palu.

\section{Metode Penelitian}

Penelitian ini menggunakan metode deskripsi dengan tipe penelitian metode survey. Metode ini bertujuan mengumpulkan informasi aktual secara rinci dan sistematis, fakta atau karakteristik tertentu. Teknik pengumpulan data dilakukan melalui studi pustaka, penelusuran data online, observasi, wawancara mendalam (indepth interview) dan dokumentasi yang dilakukan melalui studi lapangan (field research). Metode pengambilan sampel dilakukan dengan menggunakan purposive sampling, yaitu teknik penentuan sampel dengan pertimbangan tertentu, yakni a) orang yang memahami atau ahli atau lama berkecimpung dalam suatu bidang; b) orang yang pernah mendapatkan program; c) orang yang pernah mengelola program kemiskinan. Metode purposive sampling penentuan sampelnya ditentukan oleh pewawancara dengan pertimbangan bahwa sampel telah memenuhi kriteria-kriteria yang telah ditentukan sebelumnya.

\section{Hasil Penelitian dan Pembahasan}

\section{Potensi pariwisata Parigi Moutong}

Menurut Menteri Koordinator Pemberdayaan Manusia dan Kebudayaan Puan Maharani menilai Kabupaten Parigi Moutong, Sulawesi Tengah, sudah siap untuk menjadi daerah tujuan wisata baru yang unggul setelah Sail Tomini 2015. Teluk Tomini yang sangat indah serta masyarakat yang ramah tamah menandakan bahwa masyarakat Parigi Moutong sudah siap untuk menjadi daerah tujuan wisata, bahkan Puan Maharani optimistis Parigi Moutong akan menjadi daerah tujuan wisata baru Indonesia karena lewat Sail Tomini, Parigi Moutong dikenal luas di nusantara dan dunia (Asdhiana 2015b).

Pengamat kepariwisataan Sulawesi Tengah, seorang Doktor di bidang kebijakan pengembangan pariwisata Universitas Padjajaran serta Mantan Kepala Dinas Pariwisata Kabupaten Donggala yaitu Dr. Suaib Djafar mengatakan bahwa Sail Tomini 2015 merupakan salah satu pintu masuk pengembangan pariwisata secara terintegrasi khususnya di sekitar Teluk Tomini. Sail Tomini melingkupi tiga aspek yakni budaya, sumber daya alam dan atraksi. Sail Tomini menjadi ajang promosi kemaritiman, potensi alam, agro wisata dan juga budaya. Dari aspek budaya, Kabupaten Parigi Moutong merupakan daerah yang heterogen, tidak saja didiami oleh masyarakat lokal seperti Tomini, Tinombo dan Moutong, tetapi sudah berbaur dengan suku-suku lainnya seperti Bali, Jawa, Batak, dan lain-lain suku di Indonesia. Parigi Moutong menjadi semacam miniatur Indonesia (Asdhiana 2014). 
Posisi Kabupaten Parigi Moutong sebagai lintasan Segi Tiga Emas Sulawesi, yang menghubungkan Sulawesi Utara, Sulawesi Selatan dan Sulawesi Tengah, tentunya sangat strategis dan potensial untuk pengembangan kepariwisataan karena didukung oleh panorama alam yang indah sepanjang jalur jalan Trans Sulawesi tersebut. Beberapa potensi pariwisata di Parigi Moutong antara lain (Resmi Pemerintah Kabupaten Parigi Moutong) pertama, Rumah Raja Tombolotutu di Kecamatan Tinombo, sekitar $160 \mathrm{Km}$ dari kota Parigi. Raja Tombolotutu yang bergelar Pua Darawati itu, pernah menerima tahta kerajaan Moutong pada Tahun 1877 dalam usia 20 tahun. Situs sejarah ini berada persis di depan lintasan jalan Trans Sulawesi. Di dalam bangunan situs ini terdapat 2 buah senjata meriam peninggalan Raja, foto dokumentasi, perlengkapan rumah tangga dan beberapa pakaian kerajaan. Kemudian di Kecamatan Tinombo dengan jarak $\pm 160 \mathrm{~km}$ dari kota Parigi, juga terdapat rumah kediaman dan peninggalan Raja Kuti Tombolotutu yaitu raja yang berkuasa sejak tahun 1929 sampai wafat tahun 1965, menguasai kerajaan Tomini dan Moutong. Situs-situs tersebut berada di lintasan jalan Trans Sulawesi, sehingga dengan mudah dapat dijangkau.

Ke dua, Tebing Likunggavali terletak sekitar 80 kilometer di sebelah timur Kota Palu atau sekitar 22 Kilometer dari Kota Parigi, Ibukota Kabupaten Parigi Moutong. Likunggavali merupakan sebuah kawasan pegunungan yang masih alami, sejuk dan berdekatan dengan air terjun. Tebing Likunggavali merupakan dinding batu yang sangat mengagumkan, berdiri kokoh di tengah sungai. Objek wisata ini merupakan tempat olahraga panjat tebing yang curamnya mencapai 80 meter dan memiliki sekitar 12 jalur pemanjatan yang sebagian besar dapat digunakan untuk semua nomor lomba dalam olahraga panjat tebing. Federasi Panjat Tebing Indonesia (FPTI) merekomendasikan lokasi ini sebagai tempat yang tepat untuk penyelenggaraan kejuaraan panjat tebing nasional maupun internasional.

Ke tiga, Tari Pajoge Maradika dan Musik tradisional Kakula Nuada. Tari Pajoge Maradika biasanya ditampilkan pada acara perayaan pelantikan seorang raja atau pemimpin daerah, tari ini dibawakan oleh lima orang putri yang mengungkapkan ekspresi kebahagiaan menyambut kehadiran pemimpin yang baru. Tari ini diiringi musik Kakula dan seruling Lalove yaitu seruling panjang khas Parigi Moutong yang biasanya dipakai dalam upacara ritual adat. Musik tradisional Kakula Nuada adalah musik khas masyarakat Kaili yang sering ditampilkan pada acara adat ataupun mengiringi tarian tradisional.

Ke empat, Parigi Moutong terkenal dengan keragaman etnis suku dengan budaya yang beragam pula, mulai dari budaya suku Kaili, Lauje, Tajio, Tialo, Bolano, sampai pada budaya masyarakat Hindu Bali yang memperkaya khasanah budaya di tanah air. Syukuran panen Suku Lauje di Kecamatan Tomini dan Palasa yang bermakna persembahan hasil panen rakyat kepada penguasa alam semesta.

Ke lima, berbagai Upacara mau pun tarian: Upacara adat Balia masyarakat Kaili di Kecamatan Parigi, dengan iringan musik suling Lalove dan irama gendang, merupakan upaya penyembuhan bagi orang yang sakit; Upacara Ritual masyarakat Hindu Bali yang ada di Kecamatan Torue dan Parigi Selatan, adalah event menarik yang tak pernah dilewatkan oleh masyarakat sekitar.

Ke enam, Pantai Nalera dan Lumpang Batu. Obyek wisata Pantai Nalera ini berada di Desa Marantale dengan jarak tempuh sekitar 29 km dari ibukota Kabupaten Parigi Moutong. Obyek Wisata ini berada di tepi jalan Trans Sulawesi dan terdapat fasilitas penunjang bagi kepentingan pengunjung seperti penginapan dan rumah makan; sedangkan Lumpang Batu merupakan Benda Cagar Budaya yang terletak di Desa Suli Blaban, Balinggi dengan jarak tempuh $\pm 4 \mathrm{Km}$ dari jalan Trans Sulawesi. Batu ini terdiri atas 8 buah yang jaraknya berdekatan dan biasanya pada hari-hari tertentu masyarakat sekitarnya memberikan sesajen pada lesung batu tersebut yang dipercaya menolak bala dan penyakit.

Ke tujuh, Pantai Purwosari dan Upacara Melasti: merupakan salah satu obyek wisata yang ramai pengunjung. Terletak di Desa Purwosari dengan jarak tempuh $\pm 24 \mathrm{~km}$ dalam waktu $\pm 1 / 4$ jam dari ibu kota kabupaten. Selain tempatnya yang ramai pengunjung, obyek wisata bahari ini juga menjadi sasaran atau tempat untuk Melasti (Kegiatan Sakral Umat Hindu). Dari tempat ini kita juga bisa melihat panorama alam yang tidak kalah menarik dengan obyek-obyek wisata lainnya. 
Ke delapan, Pulau Kelelawar ini terdapat di desa Tomoli dengan jarak $\pm 60 \mathrm{Km}$ dengan waktu tempuh \pm 3 Jam dari kota Parigi, jarak dari pantai ke pulau dapat ditempuh \pm 10 menit dengan menggunakan perahu motor yang sudah tersedia, lokasi obyek wisata ini menjadi tempat berkembang biaknya habitat kelelawar yang berwarna kuning, coklat dan hitam. Pulau ini diapit oleh dua tanjung hutan bakau yang berbentuk pintu gerbang.

\section{Strategi pengembangan pariwisata daerah}

Semenjak Direktorat Jenderal Pengembangan Destinasi Pariwisata Kementerian Pariwisata dan Ekonomi Kreatif pada tahun 2012 menetapkan Parigi Moutong sebagai salah satu dari 29 destinasi yang memiliki daya tarik wisata nasional (Enam Lokasi Wisata Terbaik di Parigi Moutong). Parigi Moutong sudah seharusnya membenahi segala sesuatunya agar benar-benar layak menjadi suatu destinasi wisata.

Destinasi wisata adalah suatu unit geografis yang dapat berupa suatu pusat wilayah, suatu desa atau kota, daerah, pulau atau bahkan negara. Seberapa penting suatu destinasi wisata tergantung pada 3 faktor: atraksi-aksesibilitas-fasilitas. Di samping itu, perilaku sosial budaya masyarakat lokal juga sangat mempengaruhi suatu wilayah atau daerah menjadi suatu destinasi pariwisata. Apabila tidak ada jaminan penduduk lokal tidak mampu menciptakan hubungan yang baik dengan wisatawan, maka dipastikan wisatawan tidak akan memiliki keinginan berkunjung. Good relation (hubungan baik) antara penduduk lokal dan wisatawan sangat diperlukan dalam suatu kawasan pariwisata (Madiun 2010). Dalam hal ini sebenarnya Parigi Moutong telah cukup memadai untuk faktor atraksi dan aksesibilitas. Potensi alam dan kekayaan budaya daerahnya yang beragam serta akses transportasi yang lancar dan relatif dekat dengan Kota, ibukota Propinsi Sulawesi Tengah.

Yang perlu mendapat pembenahan lebih lanjut adalah persoalan fasilitas dan manajemen kepariwisataan. Objek-objek Wisata Unggulan juga lebih harus benar-benar dipersiapkan sebagai daya tarik wisatawan. Setiap objek wisata harus dijadikan sesuatu yang menjadi pusat daya tarik wisatawan dan dapat memberikan kepuasan pada wisatawan. Objek wisata dapat digolongkan menjadi tiga jenis: a) Wisata alam berupa pantai, pemandangan alam, pegunungan, hutan dan lainlain; b) Wisata budaya seperti museum, candi, galeri, dan sejenisnya; c) Wisata kegiatan contohnya berupa kegiatan outbond, kegiatan sehari-hari suatu komunitas masyarakat, tarian, karnaval, festival, dan lain sebagainya (Wardiyanta 2006).

Agar suatu pariwisata dapat terus bertahan dan mengembangkan diri, maka pariwisata perlu dipandang sebagai sebuah organisasi yang memerlukan sejumlah faktor-faktor pendukung. Faktorfaktor yang dimaksud yakni: a) perlunya adanya visi, misi dan tujuan yang jelas; dapat bersifat khas dan khusus sesuai karakteristik daerah dan maksud sistem kepariwisataan yang akan hendak dibangun; b) kualitas sumber daya manusia pendukung yang dibutuhkan harus dipersiapkan secara memadai; serta c) manajemen organisasi yang meliputi perencanaan, pengembangan, kualitas layanan. Secara ringkas, dua aspek pokok yang dibutuhkan dalam pariwisata agar dapat terus bertahan dan dapat berkembang yakni: 1) aspek kelembagaan atau aspek manajemen yakni lembaga yang dibentuk sebagai upaya pemenuhan kebutuhan rekreatif manusia; 2) aspek substansial yakni sebagai bagian dari kebudayaan manusia atau masyarakat untuk mengisi waktu senggang (Wardiyanta 2006).

Berkaitan dengan pengembangan suatu kawasan pariwisata, maka perlu diperhatikan beberapa kawasan yang sebaiknya tidak dijadikan kawasan pariwisata yakni: a) kawasan yang produktif; misalnya kawasan untuk irigasi, pertanian, sentra industri dan sebagainya seyogyanya tetap dipertahankan karena pengalihfungsian kawasan produktif bisa berdampak sangat luas; b) kawasan yang terlalu jauh atau terlalu tinggi sehingga biaya pengembangannya akan sangat mahal, atau bahkan jika dijadikan destinasi wisata akan dapat merusak lingkungan; c) kawasan yang sangat jauh dari pintu masuk pengunjung; seyogyanya suatu kawasan wisata tidak terlalu jauh dari pelabuhan, bandara atau terminal sehingga mudah dijangkau (Madiun 2010). 


\section{Sinergi pengembangan pariwisata daerah dengan pemberdayaan masyarakat}

Strategi pengembangan kawasan pariwisata dikenal terdapat dua model: pertama, model konvensional yakni model pengembangan pariwisata yang bersifat ekonomis semata, pengembangan pariwisata yang hanya memperhatikan peningkatan jumlah kunjungan tanpa memperhatikan kelestarian lingkungan dan budaya; kedua, model non konvensional yang bersifat multi tujuan, yakni bukan semata-mata ekonomis tetapi juga bersifat ekologis dan sosial budaya. Model non-konvensional menekankan pengembangan pariwisata harus berbasis pada masyarakat dan pada upaya-upaya revitalisasi kawasan, penemuan dan pelestarian kembali lingkungan serta adat budaya masyarakat (Madiun 2010). Dengan demikian, pengembangan pariwisata berdasarkan model non-konvensional menempatkan partisipasi masyarakat lokal sebagai kunci pengembangannya. Tanpa adanya keselarasan dan partisipasi masyarakat secara memadai maka keberlangsungan suatu pariwisata tidak akan berjalan dengan baik.

Strategi pengembangan pariwisata dengan model non-konvensional sangat cocok diterapkan di wilayah Parigi Moutong, karena di satu sisi wilayah Parigi Moutong dengan segala keindahan dan kekayaan alamnya memiliki potensi yang besar sebagai destinasi wisata, serta sementara di sisi lain, sebagian masyarakatnya masih di bawah garis kemiskinan. Hasil penelitian Sutikno et al. (2015) di Parigi Moutong khususnya mengambil sampel di masyarakat nelayan kurang mampu, menunjukkan bahwa sebagian besar masyarakat $(78,57 \%)$ memiliki minat yang tinggi untuk meningkatkan usahanya, yakni berkeinginan membuka usaha atau bisnis baru sebagai solusi untuk mencapai peningkatan kesejahteraan. Keinginan masyarakat ini dapat disinergikan untuk diarahkan kepada sektor-sektor yang terintegrasi dengan tujuan pengembangan pariwisata. Data lengkap hasil survei tentang keinginan masyarakat seperti pada Gambar 1.

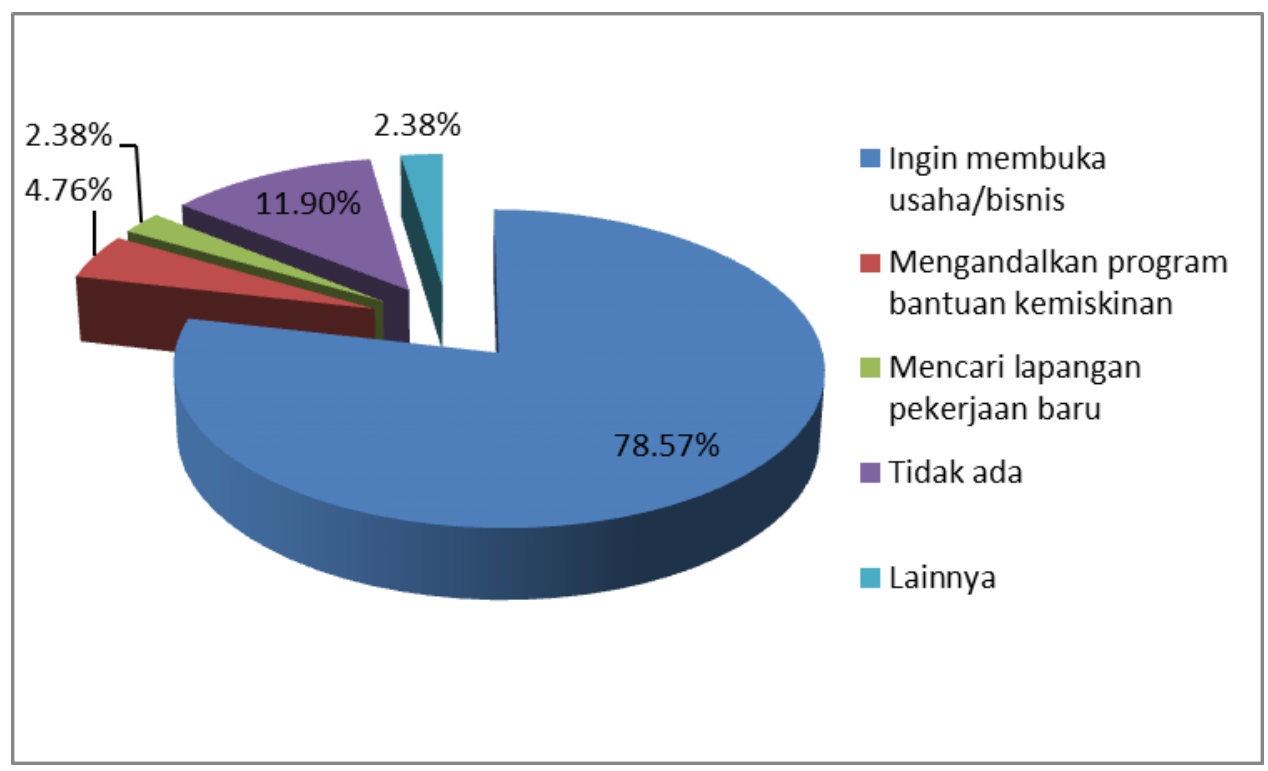

Gambar 1.

Prosentase upaya peningkatan pendapatan masyarakat. Sumber: Diolah dari hasil survei, 2015

Hasil survei menunjukkan bahwa masyarakat menginginkan inovasi bidang usaha, serta memerlukan arahan, dukungan dan penyaluran sebagai jalan keluarnya. Di satu sisi masyarakat potensial melakukan berbagai bidang usaha, di sisi lain pengembangan pariwisata daerah juga memerlukan dukungan berbagai sarana prasarana yang memerlukan partisipasi dan pelibatan masyarakat. Sinergi pemberdayaan masyarakat dengan pengembangan pariwisata sekaligus sebagai koreksi atas program pemberdayaan masyarakat yang telah dijalankan selama ini yang masih belum sepenuhnya efektif. Hasil survei Sutikno et al. (2015) menunjukkan bahwa program pemberdayaan di Parigi Moutong justru melahirkan ketergantungan baru akan bantuan langsung. Program-program pengentasan kemiskinan yang paling diharapkan justru hanya sekedar bantuan langsung (64\%). Bantuan langsung 
secara terus menerus tentu tidak dapat dilakukan karena menjadikan masyarakat tidak dapat mandiri. Di samping masyarakat juga menginginkan diadakan pelatihan-pelatihan keterampilan (13\%), dan selebihnya baru menginginkan bantuan pekerjaan dan kesehatan. Masyarakat seharusnya secara intensif terus meningkatkan potensi dan kemampuannya, tidak hanya bergantung pada berbagai bentuk bantuan langsung. Bantuan langsung hanya membantu dalam jangka pendek, dan semakin membuat masyarakat bergantung pada pihak lain.

Sebagaimana Visi Indonesia 2020 sesuai ketetapan MPR yakni Tap MPR No V/MPR/2000, dengan jelas merekomendasikan sejumlah program aksi yang harus diikuti oleh segenap pemerintah dan masyarakat Indonesia. Berbagai program aksi untuk mencapai Visi Indonesia 2020 di antaranya adalah peningkatan kualitas hidup manusia yang diukur dengan peningkatan Indeks Pembangunan Manusia; dan juga program aksi untuk menanggulangi kemiskinan dan pengangguran melalui program pemberdayaan masyarakat. Penanggulangan kemiskinan dan pemberdayaan masyarakat sangat membutuhkan sinergi semua pihak dan semua sektor, baik pemerintah, swasta dan masyarakat (Sumodiningrat 2009).

Prinsip dasarnya pengembangan pariwisata harus benar-benar bermanfaat menciptakan berbagai peluang kerja dan menciptakan diversifikasi mata pencaharian di masyarakat. Di samping juga perlu diantisipasi, karena terkadang pengembangan pariwisata juga berpotensi merubah adat istiadat, budaya, tradisi dan lain-lain kebiasaan dan cara hidup masyarakat yang sudah lama tumbuh. Di satu sisi pengembangan pariwisata dapat memajukan daerah dan meningkatkan kesejahteraan masyarakat, tetapi di sisi lain dapat pula memunculkan berbagai problematika sosial baru yang merugikan masyarakat itu sendiri jika sebelumnya tanpa didahului suatu kajian dan pertimbangan yang luas dan mendalaman, serta persiapan dan antisipasi yang komprehensif dan memadai (Wardiyanta 2006, Madiun 2010, Hasan 2011).

Bentuk-bentuk partisipasi masyarakat lokal dalam pengembangan kawasan pariwisata tidak bisa secara keseluruhan. Masyarakat lokal tidak mungkin mengelola secara total semuanya. Industri yang besar tetap harus diserahkan ke investor sedangkan masyarakat lokal mengelola sesuai kapasitas dan kemampuan masing-masing. Sebagaimana dicontohkan di pengembangan kawasan pariwisata di Nusa Dua Bali, maka masyarakat, nelayan dan penduduk asli tetap dijamin akses pemanfaatan pantai untuk mempertahankan aktivitas pekerjaan asli masyarakat tersebut, meskipun di suatu kawasan pariwisata (Madiun 2010).

Berdasarkan Rencana Tata Ruang Wilayah (RTRW) Kabupaten Parigi Moutong 2010-2030, tujuan penataan ruang wilayah Kabupaten Parigi Moutong adalah mewujudkan tatanan ruang wilayah kabupaten dalam rangka optimalisasi potensi sumber daya alam yang berbasis pada pengembangan agrobisnis, perikanan, dan pariwisata guna meningkatkan daya saing kabupaten dengan tetap mempertimbangkan daya dukung dan daya tampung lingkungan, karakteristik fisik wilayah serta kelestarian sumber daya alam (Resmi Pemerintah Kabupaten Parigi Moutong) Puan Maharani selaku Menteri Koordinator Bidang Pembangunan Manusia dan Kebudayaan pasca Sail Tomini 2015 berakhir, bermaksud melakukan evaluasi menyeluruh untuk mengetahui apakah Sail Tomini memiliki manfaat bagi daerah dan masyarakat secara jangka panjang. Puan Maharani sebenarnya meyakini bahwa Sail Tomini sebagai Sail Indonesia ke-tujuh ini akan memiliki dampak ekonomi dan kesejahteraan yang cukup luas antara lain karena menggeliatnya pembangunan di berbagai sektor yang memanfaatkan kucuran dana dari APBN dan APBD dari berbagai kementerian dan lembaga negara (Asdhiana 2015b).

Sangat penting untuk diperhatikan bahwa dalam suatu pemberdayaan masyarakat perlu menyangkut dimensi makro yakni pendekatan/model pemberdayaan yang digunakan, dan dimensi mikro yakni aspek psikologi manusianya yang selalu harus diperhatikan (Adi 2008). Pemberdayaan masyarakat merupakan proses yang memerlukan perencanaan secara menyeluruh dan terpadu, serta diperlukan adanya suatu mekanisme pemantauan yang berkelanjutan, sistem pengembangan secara sistematik, serta secara terus merevitalisasi seluruh sumber daya yang ada (Sedarmayanti 2014). 


\section{Simpulan}

Program pemberdayaan masyarakat yang belum sepenuhnya efektif selama ini disebabkan jenis program yang kurang melibatkan partisipasi masyarakat. Program-program yang ada bukannya memberdayakan masyarakat, justru sebaliknya menciptakan ketakberdayaan baru berupa ketergantungan masyarakat terhadap bantuan-bantuan yang bersifat langsung. Diperlukan suatu pendekatan baru untuk mengembangkan program pemberdayaan masyarakat. Melalui penelitian ini disimpulkan bahwa program pengembangan pariwisata memiliki prospek yang cukup untuk dikembangkan sebagai program pemberdayaan masyarakat.

Pengembangan pariwisata di Kabupaten Parigi Moutong sangat potensial dilakukan karena Kabupaten Parigi Moutong merupakan wilayah strategis yang menghubungkan berbagai wilayah lain; merupakan wilayah Segitiga Emas yang menghubungkan wilayah Gorontalo, Sulawesi Tengah dan Sulawesi Barat; bahkan juga merupakan titik yang penghubung antar negara misalnya dengan Philipina. Kabupaten Parigi Moutong juga memiliki kekayaan budaya, bahkan identik sebagai miniatur Indonesia karena terdapat beragam suku seperti: suku Kaili, Laoje, Bugis, Gorontalo, Makassar, sebagai penduduk pribumi, serta suku-suku lain yang merupakan warga transmigrasi dan pendatang dari berbagai etnis di Indonesia seperti Jawa, Bali, Ambon, Batak dan sebagainya. Kondisi alam, lokasi strategis dan keragaman sosial budaya penduduknya yang telah dimiliki oleh wilayah ini merupakan unsur-unsur penting bagi pengembangan pariwisata.

Pengembangan pariwisata di Kabupaten Parigi Moutong dapat bersinergi dengan upaya pemberdayaan masyarakat untuk menciptakan berbagai lapangan kerja alternatif untuk meningkatkan kesejahteraan masyarakat. Sebagai contoh, untuk pemberdayaan masyarakat nelayan, maka perahuperahu yang dimiliki tidak hanya dipergunakan untuk mencari ikan tetapi dapat juga dikembangkan untuk mengantar para wisatawan. Para nelayan juga dapat mengembangkan berbagai kerajinan dan kuliner untuk mendukung pariwisata. Tidak menutup kemungkinan mengembangkan 'kampung nelayan' sebagai destinasi wisata yang menarik bagi para wisatawan. Prospek pengembangan pariwisata lebih bersifat berkelanjutan secara jangka waktu dibandingkan dengan eksploitasi kekayaan laut yang pada masa tertentu dapat habis atau berkurang. Pengembangan pariwisata bersifat multi-efek terhadap berbagai sektor lain; dapat menumbuhkan sektor lain serta memiliki jangkauan waktu yang relatif lama dan tak terbatas sebagai usaha berkesinambungan untuk meningkatkan kesejahteraan sosial masyarakat.

\section{Daftar Pustaka}

Adi IR (2008a) Intervensi Komunitas: Pengembangan Masyarakat sebagai Upaya Pemberdayaan Masyarakat. Jakarta: Penerbit Rajawali.

Adi IR (2008b) Intervensi Komunitas Pengembangan Masyarakat sebagai Upaya Pemberdayaan Masyarakat. Jakarta: PT Raja Grafindo Persada.

Asdhiana IM (2014) Sail Tomini Harus Tampil Beda. Parigi: Kompas Com 24 Oktober 2014.

Asdhiana IM (2015a) Kemenpar Minta Sulteng Perkuat Promosi Pariwisata Bahari. Parigi: Kompas Com 15 September 2015.

Asdhiana IM (2015b) Parigi Moutong Siap Jadi Destinasi Wisata. Parigi: Kompas Com 19 September 2015.

Enam lokasi wisata terbaik di Parigi Moutong (2016) [Diakses 29 Juli 2016] http://lifestyle.liputan6.com.

Hasan SS (2011) Pengantar Cultural Studies: Sejarah, Pendekatan Konseptual dan Isu Menuju Studi Budaya Kapitalisme Lanjut. Yogyakarta: Ar-Ruzz Media.

Karnaji dan Sudarso (eds) (2005) Penelitian Model Pengentasan Kemiskinan Melalui Peran Serta Masyarakat Mampu di Propinsi Jawa Timur. Surabaya: Kerjasama Badan Penelitian dan pengembangan Propinsi Jawa Timur dengan LPPM Universitas Airlangga.

Madiun IN (2010) Nusa Dua Model Pengembangan Kawasan Wisata Modern. Denpasar: Udayana University Press.

Marijono (2011) Komunikasi Sosial. Jember: Penerbit Buku Pena Salsabila. 
Pemerintah Kabupaten Parigi Moutong (2016) [Diakses 3 Agustus 2016]. http://www.parigimoutongkab.go.id.

Sedarmayanti (2014) Membangun dan Mengembangkan Kebudayaan dan Industri Pariwisata. Bandung: PT Refika Aditama.

Sumodiningrat G (2009) Mewujudkan Kesejahteraan Bangsa: Menanggulangi Kemiskinan dengan Prinsip Pemberdayaan Masyarakat. Jakarta: Penerbit PT Elex Media Komputindo.

Sutikno, Soedarso \& Sukardi (2015) Pengembangan Model Pemberdayaan Masyarakat Nelayan untuk Pengentasan Kemiskinan di Kabupaten Parigi Moutong Provinsi Sulawesi Tengah. Laporan Penelitian, EPI UNET - PUPT LPPM ITS, Surabaya.

Wardiyanta (2006) Metode Penelitian Pariwisata. Yogyakarta: Penerbit CV Andi Offset. 